\title{
Viral Relapse
}

National Cancer Institute

\section{Source}

National Cancer Institute. Viral Relapse. NCI Thesaurus. Code C120600.

A recurrence of the same virus after a finding of aviremia at the end of planned or actual treatment. 